\title{
EFL Teachers Assessment Methods in Oral Communications
}

\author{
Saefurrohman, Ph.D \\ Universitas Muhammadiyah Purwokerto, Indonesia \\ saefurrohman@ump.ac.id
}

\begin{abstract}
Assessing oral communications (speaking and listening) appropriately can helps students to have a good oral language development as well as their language literacy. Thus, this study aimed at finding out the answer of a question: 'Howthe respondents' classroom assessment practices may be described in the term of methods to measure the students' skills in oral communications (speaking and listening)?"

Survey using questionnaire was used to answer the research questions. The participants of this study were taken from six high schools of Banyumas Regency, Indonesia

The research result showed that Indonesian High School English teachers were highly used teachers made assessment methods in assessing oral communication (speaking and listening) with overall mean more than 3 . Answering multiplechoice test items following a listening passage was the most methods preferred by Indonesian English teachers
\end{abstract}

Key words: Oral Communication, Classroom Assessment, Method

\section{INTRODUCTION}

Learners continually use oral communications (listening and speaking) to explore, comprehend, and communicate ideas and feelings from early childhood into adulthood. An individual's use of oral communications (listening and speaking)in day-to-day living and learning is much greater than his or her use of, for example, reading and writing. oral communications (listening and speaking)is how we communicate with others in a wide range of social contexts such as playing, eating meals, shopping, et cetera.

Oral communications (listening and speaking)development is key to the success of early literacy learners. Moreover, oral communications (listening and speaking)support the development of children's thinking and reasoning, and their reading, writing, viewing, and representing skills (MECY,2010). Thus, based on this paradigm, assessing oral communications (speaking and listening) appropriately can helps students to have a good oral language development as well as their language literacy.

In reality, not all of the English teachers in the Indonesia are fully aware in the implementation of proper assessment methods in oral communications (listening and speaking). This is because ELL students come from very different backgrounds and often face multiple challenges in the classroom. To complicate matters further, teachers lack practical, research-based information, resources, and strategies needed to access ELL students. Other challenges included the lack of tools to teach ELL students as well as appropriate assessments to diagnose student needs and measure student learning. Teachers also expressed frustration over the wide range of English language and academic levels and the fact that they received little professional development or in-service training on how to access ELL.

The educators realize that classroom assessment methods should be viewed as a process rather than as a product in which assessment purpose is not only a matter of getting the students' score and determining whether they pass the requirements or not but it is more on how to know the students' progress in learning and mediating them to get success in learning

Assessment methods itself refer to "any of a variety of procedures used to obtain information about student performance". Linn and Miller (2005).There are quite a number of assessment methods with each one of them involving a particular purpose for its use, and Cheng, Roger and $\mathrm{Hu}$ (2004) have categorized these assessment methods under; teacher-made assessment/traditional, studentsconducted assessment alternative assessment and standardized test.

This study explored on how English teachers in Indonesia practice their classroom assessment methods in oral communications (listening and speaking)

\section{METHODS}

The purpose of this study is aimed to answer a question: " How may the respondents' classroom assessment practices be described in the term of methods to measure the students skills in oral communications (listening and speaking)?"

Survey was used to answer the research questions. The participants of this study were taken from six high schools of Banyumas Regency, Indonesia.

The questionnaire was used in this research because it can reach a large number of people relatively quickly and with minimal expenditure. It consists of participants information and methods of assessment in oral communication (Speaking and Listening). Permision in using 
the questionnaire was obtained through e mail correspondence.

Survey data were analyzed by descriptive and inferential statistical methods to answer the research questions. Descriptive analyses including frequencies, percentages, and means were used to summarize the distribution of the data.

\section{RESULTS AND DISCUSSION}

\section{Result}

Indonesian Junior high school teachers classroom assessment practices in oral communication, is reported. The three categories were used to categorize the findings in each skill, namely: teacher-made assessment methods, studentconducted assessment methods, standardized testing in reading, writing, and speaking \& listening. These three categories are derived from work in educational assessment, notably Rogers (1993) and Stiggins (2004). They also represent the assessment constructs designed in this survey (Code for Fair Testing Practices for Education (1988); Standards for Teacher Competence in Educational Assessment of Students (1990) in Cheng, Rogers and $\mathrm{Hu}$ (2004).

Teacher-made assessment methods in this article refer to those assessment methods designed and administered by teachers, whereas student-conducted assessment methods are those that directly involve students' participation in the assessment process.

Indonesian English teachers classroom assessment method in speaking and listening can be seen in table 1 below.

Table 1. Frequency and Percentage Distribution of Indonesian Junior High School English Teachers' Classroom Assessment Methods in Speaking and Listening

\begin{tabular}{|c|c|c|c|c|c|c|c|c|c|}
\hline \multirow{2}{*}{$\begin{array}{l}\text { Methods I use to assess speaking } \\
\text { and listening }\end{array}$} & \multicolumn{2}{|c|}{ Always } & \multicolumn{2}{|c|}{ Quite a lot } & \multicolumn{2}{|c|}{ Not Much } & \multicolumn{2}{|c|}{ Never } & \multirow{2}{*}{ Mean } \\
\hline & $\mathrm{n}$ & $\%$ & $n$ & $\%$ & $n$ & $\%$ & $n$ & $\%$ & \\
\hline \multicolumn{10}{|l|}{ Teacher- made } \\
\hline give oral directions & 6 & $25.00 \%$ & 10 & $41.67 \%$ & 6 & $25.00 \%$ & 2 & $8.33 \%$ & 2.91 \\
\hline follow directions given orally & 6 & $25.00 \%$ & 14 & $58.33 \%$ & 4 & $16.67 \%$ & 0 & $0 \%$ & 3.08 \\
\hline $\begin{array}{l}\text { provide an oral description of an event } \\
\text { or object }\end{array}$ & 8 & $33.33 \%$ & 10 & $41.67 \%$ & 5 & $20.83 \%$ & 1 & $4.17 \%$ & 3.16 \\
\hline prepare summaries of what is heard & 7 & $29.17 \%$ & 12 & $50.00 \%$ & 4 & $16.67 \%$ & 1 & $4.17 \%$ & 3.25 \\
\hline $\begin{array}{l}\text { answer multiple-choice test items } \\
\text { following a listening passage }\end{array}$ & 10 & $41.67 \%$ & 12 & $50.00 \%$ & 2 & $8.33 \%$ & 0 & $0 \%$ & 3.50 \\
\hline take notes & 6 & $25.00 \%$ & 10 & $41.67 \%$ & 6 & $25.00 \%$ & 2 & $8.33 \%$ & 3.08 \\
\hline $\begin{array}{l}\text { retell a story after listening to a } \\
\text { passage }\end{array}$ & 9 & $37.50 \%$ & 10 & $41.67 \%$ & 5 & $20.83 \%$ & 0 & $0 \%$ & 3.04 \\
\hline \multicolumn{10}{|l|}{ Students-conducted } \\
\hline Oral reading/dictation & 12 & $50 \%$ & 8 & $33.33 \%$ & 4 & $16.67 \%$ & 0 & $0 \%$ & 3.37 \\
\hline Oral interviews/dialogues & 15 & $62.50 \%$ & 9 & $37.50 \%$ & 0 & $0.00 \%$ & 0 & $0 \%$ & 3.62 \\
\hline Oral discussion with each student & 8 & $33.33 \%$ & 10 & $41.67 \%$ & 4 & $16.67 \%$ & 2 & $8.33 \%$ & 3.21 \\
\hline Oral presentations & 10 & $41.67 \%$ & 10 & $41.67 \%$ & 4 & $16.67 \%$ & 0 & $0 \%$ & 3.54 \\
\hline Public speaking & 4 & $16.67 \%$ & 6 & $25.00 \%$ & 12 & $50.00 \%$ & 2 & $8.33 \%$ & 2.33 \\
\hline Peer assessment & 5 & $20.83 \%$ & 9 & $37.50 \%$ & 10 & $41.67 \%$ & 0 & $0 \%$ & 2.41 \\
\hline Self assessment & 6 & $25.00 \%$ & 9 & $37.50 \%$ & 7 & $29.17 \%$ & 2 & $8.33 \%$ & 2.83 \\
\hline Standardized speaking test & 6 & $25.00 \%$ & 11 & $45.83 \%$ & 7 & $29.17 \%$ & 0 & $0 \%$ & 2.83 \\
\hline Standardized listening test & 8 & $33.33 \%$ & 12 & $50 \%$ & 4 & $16.67 \%$ & 0 & $0 \%$ & 3.17 \\
\hline
\end{tabular}


From the table 1, it can be seen that the main Indonesian English teachers made assessment in speaking and listening was answer multiple-choice test items following a listening passage with the mean of 3.50 and $41.67 \%$ of respondent were always use it. The frequency and percentage distribution also showed that Indonesian Junior high school English teachers were quite a lot in using all teacher-made test in speaking and listening test consisting of give oral direction, follow direction orally, provide an oral description of an even or object, prepare summaries of what is heard, answer multiple choice test items following a listening passage, take notes and retell story after listening passage, with more than 10 respondents $(41.67 \%)$ use it.

For students-conducted assessment in speaking and listening, oral interviews/dialogues was the main assessment method used by respondents with the mean of 3.62 and $62.50 \%$ of respondents always used it. it was then followed by oral reading/dictation, oral discussion with each student and oral presentation with the mean of 3.33, 3.00 and 3.25 respectively. In contrast with this, public speaking, peer assessment and self assessment were not much used by Indonesian Junior high school English teachers.

Finally Standardized speaking and listening test were quite a lot use by respondent with $50 \%$ of respondents used it.

\section{Discussion}

The research result showed us that Indonesian Junior high school English teachers were highly used teachers made assessment methods in assessing speaking and listening with overall mean more than 3. Answering multiple-choice test items following a listening passage was the most methods preferred by Indonesian Junior high school English teachers.

It has been widely known that for oral language development assessment, summarization is one of the best assessment methods. Summarization is a high-skill exercise, which requires listeners to re-organize the ideas that have been formed while listening (Kirkland \& Saunders, 1991 in Walters and Chien, 2014). Deciding which information should be included in a summary and how the summary should be organized are normative claims, outside the bounds of the common definition, which must be answered on a case-by-case basis, and are dependent on the context, audience, and purpose of the summary (Seidlhofer, 1995) in Walters and Chien (2014). From this, the two most consistent criticisms against using summaries to assess language ability have been (1) that numerically scoring or differentiating a good summary from a poor summary is too difficult to be practical and (2) that students may not be able to produce output in the L2 commensurate with their ability to comprehend L2 input (Alderson, 2000, Wigglesworth, 2012; Yu, 2007 in Walters and Chien, 2014). This may explain why summary form of language assessment, have been so neglected, even though their potential, as a comprehensive and integrative assessment tool, is so high.

Notwithstanding that the research into the use of summaries in L2 pedagogy is underdeveloped, there have been a few notable studies which are important for this research (Walters and Chien, 2014). Rost (1994) in Walters and Chien (2014) compared L2 student summaries, completed after listening to a lecture, to expert native speaker summaries, to identify ways to improve student lecture understanding. using content and style analysis, found that the lecture was probably too difficult for the L2 learners involved in the study and that they tended to repeat or remodel chunks and phrases from the original lecture without fully grasping the meaning of their new constructions. Keck (2006) in Walters and Chien(2014), comparing L1 and L2 writers $^{\text {ee }}$ use of paraphrase in the construction of summaries, similarly found that L2 writers use more "near copies" than L1

In addition to this, retelling a story after listening passage also one of the best methods in oral language development assessment. As Johnson (1983) in Praneetponkrang and Phaiboonnugulkij (2014) stated that retelling is the most directly accessing in teaching and the reaction result of the reader from the text.

Retelling signifies the reader or the listener understanding of learning's and creates new construction of character and reflects in retelling apprehension. Retelling helps readers or listeners to respond to the structure of stories regarding the personal explication of each message. It is the process of involving children in creating text and also allows interoperability between adults and young learners. Retelling motivates learners about the text for both integration and personalization that also helps learners view what the content components of the message and how the text related to their experiences. Also, Koskinen et al. (1988:892) in Praneetponkrang and Phaiboonnugulkij (2014) explicated that retelling is a useful teaching technique to encourage students in communication, and improves an oral language comprehension. It provides the readers to separate between the point of ideas and supporting details and retelling helps students to understand the text's meaning. It advocates students to learn about the story's elements such as plot, setting, and characters.

Indonesian Junior high school English teachers prefer using oral interview/dialogue than other test as students-conducted assessment. This finding was in line with Rahayu's study (2010) on study in which she investigated the impact of interview on students speaking performance. The result of her research showed that interview is an effective technique in teaching speaking. The improvement can be seen in the form of students' behaviour and students' score. The students' score of speaking increased after the research was conducted. The mean score of pre-test 1 was 1.23. It becomes 1.49 in post-test 1 , and it increased again to 
1.77 in post-test 2 . Besides, there is a change of students' attitude in speaking that becomes more active. Moreover, interview creates an interesting atmosphere in the classroom. From the research, it is known that interview gave many advantages in teaching speaking. They were: (1) interviews are motivating, therefore they can motivate the students to be better in speaking English; (2). interviews invite the students to speak actively; (3). interviews involve equal participation from both slow and fast learners; (4). interviews in pairs or in groups contribute to an atmosphere of healthy competition in a non-stressful situation; (5). interviews can be used in any language teaching situation and with any skill area such as reading, writing, speaking or listening; and (6). Interviews provide immediate feedback for the teacher. However, there were also disadvantages in employing interview in teaching speaking. Sometimes, interview resulted noisiness that can make the students out of control and disturb other classes (Rahayu, 2010)

In contrast with this, Indonesian Junior high school English teachers were rarely used public speaking, self and peer assessment as alternative assessment in speaking and listening.

In most English language classrooms, especially in English as a second/foreign language (ESL/EFL), the instructors are often faced with the daunting task of gettingthe learners to overcome their anxiety to do public speaking in the targetlanguage (Munoz, et all,2011). According to William and Thomson (2007) threemajor factors that could contribute to this arecultural factors, linguistic factors, and psychological oraffective factors. Anxiety, often linked to feelings ofuneasiness, frustration, self-doubt, apprehension or worry,affects the ESL/EFL learners significantly. Munoz, et all (2011) said that for an ESLlearner public speaking assessment as performing a task in frontof the class increases communicative stress, and is predictedto lead to a reduction in fluency and complexity.

Peer and self assessment were also one of the lowest methods used among the respondents. Indeed teaching and learning process can be more successful when students are involved in developing the assessment process. Meisels, Atkins-Burnett, Xue\& Bickel (2003), reveal how student involvement with work sample based performance assessments yields similar gains on standardized test performance when compared with students who did not experience the embedded performance assessment. Thus as teachers, It is helpful to introduce students to the concepts and elements of assessment against specified criteria and on how to judge their own and others' contributions using self and peer assessment (William and Thomson, 2007).

In brief,Students also will need to be assisted to develop criteria that match the learning outcomes with regards to the output and process of learning. If assessment criteria for each element are set up and clearly communicated, it will also change the role of teachers as facilitator.

\section{CONCLUSION}

The research result showed that Indonesian high school English teachers were highly used teachers made assessment methods in assessing speaking and listening with overall mean more than 3. Answering multiple-choice test items following a listening passage was the most methods preferred by English teachers

\section{REFERENCES}

Cheng, Liying., Rogers, Todd., \& Hu, Huiqin. (2004). ESL/EFL Instructors' Classroom Assessment Practices: Purposes, Methods, and Procedures Language Testing 2004 21: $360 . \quad$ DOI: 10.1191/02655322041t288oa. http://tj.sagepub.com/content/21/3/360

Linn, R. L., \& Miller, M. D. (2005).Measurement and assessment in teaching (9th ed.). UpperSaddle River, NJ: Pearson Prentice Hall

Manitoba Education, Citizenship and Youth (MMECY).(2010). Listening And Speaking :First Steps Into Literacy. Retrieved from: http://www.edu.gov.mb.ca/k12/cur/ela/list_speak/1 istening speaking.pdf.

Muñoz, Ana Patricia., Palacio, Marcela.,\& Escobar, Liliana. (2011). Teachers' Beliefs About Assessment in an EFL Context in Colombia. PROFILE Vol. 14, No. 1, April 2012. ISSN 1657-0790. Bogotá, Colombia. Pages 143-158.

Meisels, S., Atkins-Burnett, S., Xue, Y., \& Bickel, D. D. (2003). Creating a system of accountability: The impact of instructional assessment on elementary children's achievement scores.Educational Policy Analysis Archives. 11(9), 19 pp. Retrieved from http://epaa.asu.edu/eapp/v11n9/

Praneetponkrang ,Sasitorn\&Phaiboonnugulkij, Malinee. (2014). The Use of Retelling Stories Technique in Developing English Speaking Ability of Grade 9 Students. Advances in Language and Literary Studies ISSN: 2203-4714 Vol. 5 No. 5; October 2014

Kristin Rahayu (2010). Improving Speaking Skill By Using Interview (A Classroom Action Research in the Eleventh Grade of SMA Negeri 1 Surakarta in the Academic Year 2009/2010). Master's Thesis, Unpublished. Teacher Training and Education Faculty.SebelasMaret University.

Rogers, N. (1993). Improving the Quality of Learning in Law Schools by Improving Student 
Stiggins, R. (2004). New Assessment Beliefs for a New School.Phi Delta Kappan, 86, 2227Assessment.Legal Education Review Journal Volume 4(1).

Walters, Brent G \&Chien, Ching-ning. . (2014). College EFL Teachers" Perspectives on Listening Assessment and Summarization for a Specific Task. Journal of Language Teaching and Research, Vol. 5, No. 2, pp. 313-322, March 2014.

Wiliam, D., \& Thompson, M. (2007).Integrating Assessment with Instruction: What will it Take to Make it Work?. In C. A. Dwyer (Ed.), The future of assessment: shaping teaching and learning (pp. 53-82). Mahwah, NJ: Lawrence Erlbaum Associates 